\title{
Teachers' Knowledge, Beliefs, and Attitudes about Climate Change
}

\author{
Dominique-Esther Seroussi ${ }^{1}$, Nathan Rothschild ${ }^{1,4}$, Eyal Kurzbaum ${ }^{2}$, Yosi Yaffe ${ }^{3,4}$ \& Tahel Hemo ${ }^{5}$ \\ ${ }^{1}$ Department of Science Teaching, Ohalo Academic College, Katzrin, Israel \\ ${ }^{2}$ Shamir Research Institute, University of Haifa, Katzrin, Israel \\ ${ }^{3}$ School of Education, Ohalo Academic College, Katzrin, Israel \\ ${ }^{4}$ Tel Hai Academic College, Kyriat Shemona, Israel \\ ${ }^{5}$ Everett High School, Hatsor HaGelilit, Israel \\ Correspondence: Dominique-Esther Seroussi, Department of Science Teaching, Ohalo Academic College, PO \\ Box 222, Katzrin 12900, Israel. Tel: 972-54-802-5155. E-mail: domestherseroussi@gmail.com
}

Received: March 25, 2019

doi:10.5539/ies.v12n8p33
Accepted: April 30, $2019 \quad$ Online Published: July 29, 2019

URL: https://doi.org/10.5539/ies.v12n8p33

\begin{abstract}
A sample of eighty Israeli in-service teachers filled out a questionnaire assessing their beliefs about the existence and the anthropogenic origin of climate change, their knowledge about the causes and consequences of climate change and the actions which can be taken to remediate it, as well as their level of concern about it and their readiness to act and teach in a climate-friendly way. The results show gaps in knowledge especially regarding the consequences of climate change, and misconceptions about the causes of climate change. The anthropogenic nature of climate change is well admitted. The percentage of teachers ready to take action to slow down climate change is smaller than the percentage of teachers understanding climate change. There is a significant correlation between knowledge about the consequences of climate change and concern about it and readiness to act. These results lay out the path for possible improvement of climate change instruction in teachers' preparation programs.
\end{abstract}

Keywords: global warming, climate change, in-service teachers, misconception, knowledge, beliefs, attitudes

\section{Introduction}

\subsection{Climate Change and Teachers' Education}

Climate change is one of the major ecological problems in the present time (United Nations, 2015). The expression "climate change" has been adopted by the scientific community in recent years to describe the phenomena caused by increased heat retention in the atmosphere, instead of "global warming" (Benjamin, Por, \& Budescu, 2017). The purpose of this semantic shift was to express the variety of climate phenomena linked to the change in world's global temperature (not only an increase in hot temperatures, but also cases of extreme cold weather, rising sea level, and changes in wildlife cycles), and to take into account the variety of sources influencing the earth's climate (human activity but also natural factors like variations in oceans temperature or in volcanic activity). Eventually, the term climate change has been shown to be linked to a less clear-cut conception of the human responsibility for the earth's climate than the term global warming (Benjamin et al., 2017).

In order to act in an environmental conscious way in what concerns climate change (Fortner, 2001) and to contribute to the protection of the environment as a part of various decision-making systems at any level of the society, citizens need to be well-informed about the problem and to make up their mind on this issue (Ekborg \& Areskoug, 2006). Yet the specificity of the climate change issue, unlike other socio-scientific issues like air pollution for instance, is that it deals with a danger which is not yet completely visible, and therefore people's understanding of this issue can be complicated by information negating the danger. Therefore, along with the contribution of general media, the systematic instruction provided by teachers in schools about climate change is important for the construction of young people's knowledge and beliefs of young people in this field (Dupigny-Girouz, 2010; Ekborg \& Areskoug, 2006; Schreiner, Henriksen, Kirkeby, \& Pål, 2005). Strong knowledge about climate change is shown to help teachers succeed in this task (McNeal, Petcovic, \& Reeves, 2017; Sadler, Amirshokoohi, Kazempour, \& Allspaw 2006), and their beliefs about the causes of climate change are known to influence their pupils (Stevenson, Peterson, \& Bradshaw, 2016).

Yet there is a concern worldwide that elementary and junior high-school teachers are not all well-equipped nor are 
they motivated to fulfill their role. The results concerning in-service teachers (Dawson, 2012; Herman, Feldman, \& Vernaza-Hernandez, 2017; Hermans, 2016; Karami, Seyed, Jafari, \& Hendi, 2017; Liu, Roehrig, Bhattacharya, \& Varma, 2015; McNeal et al., 2017; McNeal, Walker, \& Rutherford, 2014; Plutzer \& Hannah, 2018; Raath \& Hay, 2016; Seow \& Ho, 2016; Wise, 2010) are confirmed by more numerous publications concerning pre-service teachers. The knowledge gaps and distorted beliefs observed twenty years ago in pre-service teachers' (Boyes \& Chambers, 1995; Dove, 1996; Fortner, 2001; Groves \& Pugh, 1999; Khalid, 2001; Papadimitriou, 2004) are diminishing today but they still exist. The proportion of teachers holding a sound understanding of the causes of climate change has increased (Dawson, 2012). But teachers' literacy level depends on the population observed (Herman et al., 2017), and even teachers who understand the causes of climate change, often have a restricted knowledge of its consequences and remediation ways (McNeal et al., 2014). Moreover, numerous teachers who are literate in this field are still avoiding teaching the topic (Dawson, 2012) or teach it from a skeptical point of view which does not contribute to their students' environmental education as reported in the United States by Plutzer and Hannah (2018).

Israel is a multicultural Middle-Eastern country with European and American influences and heavy national concerns besides ecological problems. Like in most countries, insufficient literacy is observed in Israeli schools students in what concerns climate change (Negev, Sagy, Garb, Salzberg, \& Tal, 2008). Comparing Israeli teachers to their colleagues in other countries in regard to climate change literacy might give some cues about the influence of general characteristics on teachers' knowledge and beliefs about climate change. As a first step in this direction, we examined here a sample of Israeli elementary and middle school teachers in terms of portraying their knowledge level, beliefs and attitudes in what concerns climate change.

\subsection{Existing Data on Teachers' Knowledge Beliefs and Attitudes about Climate Change}

The gains made by learners when processing information dealing with a socio-scientific issue such as climate change can be grouped into three categories. The first one is knowledge. The second one is beliefs. Beliefs are described as "propositions held to be true" (Pajares, 1992). Indeed, like other scientific models which have been the center of some public controversy, the model describing the causes and consequences of climate change for the world, is still conceived by certain individuals as a model that has no immediate proof, even if nowadays there is no doubt about it in the scientific community (Lambert \& Bleicher, 2013). Moreover, since climate change describes phenomena that people do not experience themselves, it is intuitively harder to believe to than a model describing present phenomena. And therefore for some people, the adhesion to some aspects of the model describing climate change (the mere existence of climate change, the human causes of climate change, the proximity of its consequences) is perceived as a belief and not as knowledge, and is controlled by the corresponding cognitive mechanisms involving emotions and social or personal influences (Capstick \& Pigeon, 2014; Lorenzoni \& Pidgeon, 2006; Weintrobe, 2013). The third dimension that develops in people's mind about climate change is attitudes. Attitude can be defined as 'a psychological tendency that is expressed by evaluating a particular entity with some degree of favor or disfavor' (Eagly \& Chaiken, 1993). Indeed, as a socio-scientific issue, climate change is linked to practical behavior: changes in energy consumption as well as more general economic steps. Therefore, receiving information on this topic is automatically accompanied by the formation of attitudes concerning these practical steps (Ajzen, 2002). In this research, we shall address these three dimensions.

In what concerns knowledge, the greenhouse effect is not well understood by all in-service teachers. In-service teachers hold misconceptions about the causes and the consequences of climate change (Liu et al., 2015) which fit the misconceptions observed in the global population and in particular in pre-service teachers. The most commonly observed misconception among in-service teachers (McNeal et al., 2014; Herman et al., 2017) is a confusion between the greenhouse effect and global warming also observed among pre-service teachers (Arslan, Cigdemoglu, \& Moseley, 2012). Another misconception is the erroneous attribution of the responsibility for global warming to the phenomenon of the depletion of the ozone layer, which is observed among in-service teachers (Herman et al., 2017) as well as pre-service teachers (Arslan et al., 2012; Boyes \& Chambers, 1995; S. Cimer, A. Cimer, \& Ursavas, 2011; Khalid, 2001; Lambert, Lindgren, \& Bleicher, 2011; Papadimitriou, 2004) and university students (Morgan \& Moran, 1996). Pre-service teachers are also often reported to attribute climate change to atmospheric pollution (Arslan, et al., 2012; Ikonomidis, Papanastasiou, Melas, \& Avgoloupis, 2012).

The belief that there is no human responsibility for climate change is an important misconception found among pre-service teachers (Hestness, McDonald, Breslyn, McGinnis, \& Mouza, 2014) as well as in-service teachers (Plutzer \& Hannah, 2018; Wise, 2010). In some cases, some pre-service teachers were even found to ignore climate change itself (Higde, Oztekin, \& Sahin, 2017). Among industrialized countries, there seems to be a difference between the USA and Europe in this respect (Lorenzoni \& Pidgeon, 2006), and American people in comparison to European people seem to adopt more often the belief that climate change is still a controversial idea 
and to be less worried by the phenomenon. According to Plutzer and Hannah (2018), 13 to $16 \%$ of teachers in the United States still think that climate change is due to natural causes and many others say they are unsure.

Today, even if the proportion of pre-service teachers having a fair understanding of the causes of climate change increases, the proportion of teachers who understand its consequences and the way to remediate to it is smaller (McNeal et al., 2014): for instance many pre-service teachers (Ikonomidis et al., 2012) and in-service teachers (Shea, Mouza, \& Drewes, 2016) think that every environment friendly action can help reduce climate change.

The attitudes of teachers regarding practical steps to be taken in order to slow down climate change relate both to their own behavior (the enactment of climate-friendly steps or decisions) and to their teaching practice. As presented here, climate change continues to be recognized by many teachers as a controversial topic, and therefore teachers are frequently reluctant to teach it even if they are literate in this field (Dawson, 2012; Hodson, 2013; McGinnis \& Simmons, 1999; Sadler et al., 2006; Seow \& Ho, 2016). Some teachers overcome their reluctance by choosing to teach the two opposite beliefs about the human responsibility in climate change, and this makes their teaching hide the actual problem (Herman et al., 2017; Plutzer \& Hannah, 2018; Plutzer, Hannah, Rosenau, McCaffrey, Berbeco, \& Reid, 2016; Wise, 2010). Alternatively many teachers teach the topic of climate change without linking it to the relevant economic and political issues (Herman et al., 2017 in the US) or to the need for citizen incentive (Hermans, 2016 in Finland). Regarding attitudes in respect to environmentally friendly behavior, some authors complain that there are still numerous teachers who display a lack of willingness to act in an environment friendly way (Ambusaidi, Boyes, Stanisstreet, \& Taylor, 2012; Karami et al., 2017).

\subsection{The Influence of Academic Courses on Teacher's Knowledge and Beliefs}

In many teachers' preparation programs, there is still no general obligation to learn about important environmental problems (Hestness et al., 2011) and even science students do not always encounter this topic in their curriculum. In these cases the instruction received by pre-service teachers fails to improve teachers' knowledge and awareness about climate change (Boon, 2016). Yet if a course about environmental issues is included in teacher preparation, its efficiency is generally reported to be high (Ekborg \& Areskoug, 2006): even a short course can significantly increase the understanding of climate change issues (Lombardi \& Sinatra, 2012). Several studies report how courses in teachers' preparation programs have succeeded in changing pre-service teachers' understanding and beliefs about climate change (Bell, Matkins, \& Gansneder, 2011; Hastürk \& Dogan, 2016; Lambert \& Bleicher, 2013). Various strategies are developed to improve the efficacy of pre-service teacher's instruction about climate change. Misconception based instruction is used as way of correcting knowledge gaps (McCuin, Hayhoe, \& Hayhoe, 2014). The improvement of teachers' epistemological knowledge (Bell et al, 2011; Matkins \& Bell, 2007) and pedagogical skills related to climate change (Lambert, \& Bleicher, 2017), is seen as a way to help them to deal with ongoing controversies concerning this issue (Shea et al., 2016). Finally, concrete actions performed on campus in the institutions where pre-service teachers learn (Avissar, Alkaher, \& Gan, 2018) are proposed as a way of increasing teachers' involvement in ways of living that oppose climate change.

\subsection{Purpose and Research Questions}

The investigations presented in this paper were aimed at answering the following research questions:

1) What is the knowledge of Israeli teachers about climate change?

2) What are their beliefs about climate change?

3) How much are Israeli teachers motivated to act in order to help to improve the situation?

\section{Method}

\subsection{Participants}

The participants of the research were a sample of 80 elementary and middle school teachers in Northern Israel, and among them, 36 science teachers ( 19 of them having a course containing information about climate change) and 44 non-science teachers ( 6 of them having a course containing information about climate change), approximately equal proportions of Hebrew and Arabic speakers, and 36 teachers having taken some course containing information about climate change. Teachers were approached in different settings (schools, teachers' college, and neighborhood) by a research assistant and were requested to fill out the research questionnaire, after it received approval from the board of ethics in our college.

\subsection{Research Questionnaire}

The research questionnaire contained numerous items from two published questionnaires about global warming and several original items (see hereunder). The first questionnaire used was excerpted from the Six Americas' Survey developed by the Yale Project on Climate Change Communication (Leiserowitz, Maibach, Roser-Renouf, 
\& Smith, 2011; Leiserowitz, Smith, \& Marlon, 2012) which has been used in several recent research works with teachers (Lambert \& Bleicher 2013; Shea et al., 2016; Stevenson et al., 2016; Valdez, Peterson, \& Stevenson, 2018 ) as it reflects better than earlier designed questionnaires the knowledge that has developed recently in the global population about climate change. The second questionnaire was developed by Tobler, Visschers, and Siegrist (2012) in Switzerland and contains more items concerning beliefs. In the questionnaire we administered to the teachers, we used the expression "global warming" instead of "climate change" because it is the expression used in the popular media (Lineman, Do, Ji-Yoon, Gea-Jae, 2015) and therefore it is the expression that will be best understood by our population. In the questionnaires, the formula $\mathrm{CO}_{2}$ was always accompanied by the explicit name of the gas, carbon dioxide, to avoid confusing teachers who do not know the formula.

The dimensions we tried to measure in our questionnaire were

Knowledge:

- Knowledge about the mechanism of the greenhouse effect and of global warming

- Knowledge about the causes of climate change

- Knowledge about the consequences of climate change

- Action-related knowledge about climate change

Beliefs:

- Belief that climate change is happening

- Belief that scientists agree on the model of global warming

- Belief about the human causes of global warming

Attitudes:

- Concern for the future concerning climate change on a 4-point Likert scale

- Readiness to act in order to slow climate change, measured by 4 original items on which teachers' agreement was graded on a 4-degree Likert scale: readiness to make specific efforts, readiness to make real changes in way of life, readiness to teach about global warming and readiness to influence people more generally.

\section{Results and Discussion}

\subsection{Knowledge about Global Warming}

A salient characteristic of the teachers we studied in comparison to the people researched in the two studies that employed the questionnaires we used (Leiserowitz et al., 2012; Tobler et al. 2012), was the large proportion of respondents in our sample who admitted that they did not know the right answers on the questionnaire. Therefore we present our results in two different formats. One format stresses the teachers who chose the right sentences among those presented in the questionnaire, thus merging respondents who said they did not know and those who held erroneous beliefs. The second format computes the percentage of teachers choosing the right sentence among the teachers who declared they knew the answer. 
Table 1. Knowledge about the causes of climate change. (-) Denotes items with an incorrect statement. Accordingly, responses were reversed to indicate correct and wrong answers (Tobler et al., 2012). In parentheses, the percentage of subjects for each answer when excluding subjects who declared they do not know

\begin{tabular}{|c|c|c|c|c|c|c|}
\hline & \multicolumn{3}{|c|}{ Tobler 2012} & \multicolumn{3}{|c|}{ Present sample } \\
\hline & $\%$ right & $\begin{array}{c}\% \\
\text { wrong }\end{array}$ & $\begin{array}{c}\% \text { do } \\
\text { not } \\
\text { know }\end{array}$ & $\%$ right & $\begin{array}{c}\% \\
\text { wrong }\end{array}$ & $\begin{array}{c}\% \text { do } \\
\text { not } \\
\text { know }\end{array}$ \\
\hline $\begin{array}{l}\text { 1.The global } \mathrm{CO}_{2} \text { concentration in the atmosphere has increased } \\
\text { during the past } 250 \text { years }\end{array}$ & $87(90)$ & $10(10)$ & 3 & $55(95)$ & $3(5)$ & 42 \\
\hline $\begin{array}{l}\text { 2. In past centuries, the average spatial extent of the snow blanket } \\
\text { in the northern hemisphere remained unchanged. }(-)\end{array}$ & $83(89)$ & $10(11)$ & 7 & $67(87)$ & $10(13)$ & 23 \\
\hline 3. Global warming is mainly caused by human activities*. & $82(90)$ & $9(10)$ & 9 & $70(90)$ & $8(10)$ & 22 \\
\hline $\begin{array}{l}\text { 4. With a high probability, the increase of } \mathrm{CO}_{2} \text { is the main cause } \\
\text { of climate change. }\end{array}$ & $79(88)$ & $12(13)$ & 10 & $52(80)$ & $13(20)$ & 35 \\
\hline $\begin{array}{l}\text { 5. In Israel, the number of hot days has increased in past } \\
\text { centuries. }\end{array}$ & $72(85)$ & $14(16)$ & 15 & $77(96)$ & $3(4)$ & 20 \\
\hline $\begin{array}{l}\text { 6. Climate change is mainly caused by natural variations (such as } \\
\text { changes in solar radiation intensity and volcanic eruptions). (-) }\end{array}$ & $70(82)$ & $16(18)$ & 15 & $57(76)$ & $18(24)$ & 25 \\
\hline $\begin{array}{l}\text { 7. The last century's global increase in temperature was the } \\
\text { largest during the past } 1000 \text { years. }\end{array}$ & $67(74)$ & $23(26)$ & 10 & $45(94)$ & $3(6)$ & 52 \\
\hline $\begin{array}{l}8 \text {. The ' } 90 \text { s were globally the warmest decade during the past } \\
\text { century. }\end{array}$ & $52(59)$ & $35(41)$ & 12 & $25(62)$ & $15(38)$ & 60 \\
\hline $\begin{array}{l}\text { 9. If today's greenhouse gas content in the atmosphere stabilized, } \\
\text { the climate would still warm for at least another } 100 \text { years. }\end{array}$ & $48(54)$ & $41(46)$ & 11 & $22(49)$ & $23(51)$ & 55 \\
\hline $\begin{array}{l}\text { 10. In the last century, the temperature increase in Israel was } \\
\text { significantly smaller than the global average. }(-)\end{array}$ & $44(53)$ & $39(47)$ & 17 & $25(62)$ & $15(38)$ & 60 \\
\hline $\begin{array}{l}\text { 11. Today's global } \mathrm{CO} 2 \text { concentration in the atmosphere already } \\
\text { occurred in the past } 650,000 \text { years. }(-)\end{array}$ & $26(34)$ & $50(66)$ & 24 & $23(64)$ & $13(39)$ & 64 \\
\hline
\end{tabular}

*(in the original survey the sentence included "the increase in greenhouse gases" and we changed that supposing a low acquaintance of the teachers in our sample with the link of this phenomena with global warming - which proved to be true).

Only the general awareness about the tendency of the climate to become hotter (Items 2, 5, 7, 8, 10 in Table 1) seemed to be higher than that observed in the European study. Since the climate conditions in Israel are generally hotter than in Switzerland, this may be due to the influence of the actual feeling that the weather is hot on the assimilation of knowledge concerning climate change (Liu et al., 2015; Risen \& Critcher, 2011; Schuldt \& Roh, 2014).

Yet knowledge about the greenhouse effect (Table 2) was confused. 
Table 2. Knowledge about the greenhouse effect. (-) Denotes items with an incorrect statement. Accordingly, responses were reversed to indicate correct and wrong answers. (Tobler et al., 2012). In parentheses, the percentage of subjects for each answer when excluding subjects who declared they do not know

\begin{tabular}{|c|c|c|c|c|c|c|}
\hline & \multicolumn{3}{|c|}{ Tobler 2012} & \multicolumn{3}{|c|}{ Present sample } \\
\hline & $\%$ right & $\begin{array}{c}\% \\
\text { wrong }\end{array}$ & $\begin{array}{c}\% \text { do } \\
\text { not } \\
\text { know }\end{array}$ & $\%$ right & $\begin{array}{c}\% \\
\text { wrong }\end{array}$ & $\begin{array}{l}\% \text { do } \\
\text { not } \\
\text { know }\end{array}$ \\
\hline 1.Burning oil among other things, produces $\mathrm{CO}_{2}$ & $90(93)$ & $7(7)$ & 3 & $75(94)$ & $5(6)$ & 20 \\
\hline $\begin{array}{l}\text { 2.The warming of the earth's atmosphere caused by the } \\
\text { greenhouse gases is called the greenhouse effect }\end{array}$ & $86(94)$ & $5(6)$ & 9 & $70(90)$ & $8(10)$ & 22 \\
\hline 3.Carbon dioxide $\left(\mathrm{CO}_{2}\right)$ is a greenhouse gas. & $85(90)$ & $9(10)$ & 6 & $42(74)$ & $15(26)$ & 43 \\
\hline 4.Greenhouse gases partly retain the Earth's heat radiation. & $66(77)$ & $20(23)$ & 14 & $47(82)$ & $10(18)$ & 43 \\
\hline 5. $\mathrm{CO}_{2}$ is harmful to plants. (-) & $61(84)$ & $12(16)$ & 27 & $65(84)$ & $12(16)$ & 23 \\
\hline 6. Without humans, there would be no greenhouse effect. $(-)$ & $51(81)$ & $11(19)$ & 37 & $35(47)$ & $40(53)$ & 25 \\
\hline 7The ozone hole is the main cause of the greenhouse effect. (-) & $44(71)$ & $18(29)$ & 38 & $32(44)$ & $41(56)$ & 27 \\
\hline $\begin{array}{l}\text { 8. At the same quantity, } \mathrm{CO} 2 \text { is more harmful to the climate than } \\
\text { methane. (-) }\end{array}$ & $30(34)$ & $58(66)$ & 13 & $27(57)$ & $20(43)$ & 53 \\
\hline 9. Water vapor is a greenhouse gas. & $10(40)$ & $15(60)$ & 75 & $28(65)$ & $35(35)$ & 37 \\
\hline
\end{tabular}

For instance, $42 \%$ of the teachers agreed that $\mathrm{CO}_{2}$ is a greenhouse gas, $47 \%$ agreed that greenhouse gases partly retain the Earth's heat radiation, $70 \%$ recognized the greenhouse effect as the warming of the earth's atmosphere caused by the greenhouse gases. And nevertheless, when asked what the greenhouse effect refers to (Table 3), only $8 \%$ chose the sentence stating that it consists of gases in the atmosphere that traps the heat. This means that every teacher probably understood only a part of the explanation of the greenhouse effect and few understood the whole phenomenon.

Table 3. Teachers' conceptions of the greenhouse effect

\begin{tabular}{ll}
\hline What does the greenhouse effect refer to? & \\
\hline Gases in the atmosphere that trap the heat & $8 \%$ \\
The Earth's protective ozone layer & $33 \%$ \\
Pollution that causes acid rain & $40 \%$ \\
How plants grow & $1 \%$ \\
Do not know & $18 \%$ \\
\hline
\end{tabular}

The most frequent misconception about the greenhouse effect in our sample (Table 3) was "pollution that causes acid rain". The confusion between the greenhouse effect and the dilution of the ozone in the stratosphere which is observed in numerous studies also appeared in our sample at a high percentage. The proportion of teachers holding this misconception in our sample (33\%) fitted the proportion found in other studies on pre-service elementary and high-school teachers (Khalid, 2001) or on university students (Wachholz, Artz, \& Chene, 2014). We think that the overall disordered knowledge displayed by the teachers stems from the reception of information about global warming from non-systematical sources, like mass media or information sheets of consumption products, which leads people to know the words but does not help them understand their meaning.

The items checking knowledge about the consequences of climate change (Table 4) showed gaps especially in what concerns regional differences in climate change and health-related consequences. 
Table 4. Knowledge concerning the expected consequences of climate change. (-) Denotes items with an incorrect statement. Accordingly, responses were reversed to indicate correct and wrong answers. (Tobler et al., 2012). In parentheses, the percentage of subjects for each answer when excluding subjects who declared they do not know

\begin{tabular}{|c|c|c|c|c|c|c|}
\hline \multirow[b]{2}{*}{$\begin{array}{l}\text { "For the next few decades, the majority of climate scientists } \\
\text { expect..." }\end{array}$} & \multicolumn{3}{|c|}{ Tobler 2012} & \multicolumn{3}{|c|}{ Present sample } \\
\hline & $\%$ right & $\begin{array}{c}\% \\
\text { wrong }\end{array}$ & $\begin{array}{c}\% \text { do } \\
\text { not } \\
\text { know }\end{array}$ & $\%$ right & $\begin{array}{c}\% \\
\text { wrong }\end{array}$ & $\begin{array}{r}\% \text { do } \\
\text { not } \\
\text { know }\end{array}$ \\
\hline $\begin{array}{l}1 \ldots \text { an increase in extreme events, such as droughts, floods, and } \\
\text { storms. }\end{array}$ & $96(96)$ & $3(3)$ & 1 & $81(92)$ & $7(8)$ & 12 \\
\hline $\begin{array}{l}2 \ldots \text { a warmer climate to increase the melting of polar ice, which } \\
\text { will lead to an overall rise of the sea level. }\end{array}$ & $93(96)$ & $4(4)$ & 3 & $78(94)$ & $5(6)$ & 17 \\
\hline $\begin{array}{l}\text { 3. The health effect that might come up due to climate change } \\
\text { during the next } 50 \text { years concerns only humans who reside in } \\
\text { tropical areas. (-) }\end{array}$ & $82(87)$ & $12(13)$ & 6 & $38(56)$ & $30(44)$ & 32 \\
\hline 4.....a cooling-down of the climate. $(-)$ & $82(87)$ & $12(13)$ & 6 & $62(88)$ & $8(12)$ & 30 \\
\hline $\begin{array}{l}5 \ldots . . \text { a warmer climate to increase water evaporation, which will } \\
\text { lead to an overall decrease of the sea level. }(-)\end{array}$ & $77(89)$ & $9(11)$ & 14 & $23(30)$ & $54(70)$ & 23 \\
\hline $\begin{array}{l}6 \ldots \text {... a warmer climate will foster the spread of infectious diseases } \\
\text { (such as yellow fever or malaria) in the northern regions. }\end{array}$ & $69(76)$ & $22(24)$ & 9 & $67(89)$ & $8(11)$ & 25 \\
\hline $\begin{array}{l}7 \ldots \text { a warmer climate would lead to an increase of heat-related } \\
\text { cardiovascular problems in Israel, too. }\end{array}$ & $67(74)$ & $23(26)$ & 10 & $52(84)$ & $10(16)$ & 38 \\
\hline 8 ....the climate to change evenly all over the world. (-) & $54(69)$ & $24(31)$ & 22 & $32(54)$ & $27(46)$ & 41 \\
\hline $\begin{array}{l}9 . . . \text { that with a warmer climate, the sea water will warm and } \\
\text { expand, which will lead to a rise in the sea level. }\end{array}$ & $51(74)$ & $18(26)$ & 31 & $54(75)$ & $18(25)$ & 28 \\
\hline $10 \ldots$. a precipitation increase in every region worldwide. $(-)$ & $43(64)$ & $24(36)$ & 33 & $42(68)$ & $20(32)$ & 38 \\
\hline $\begin{array}{l}\text { 11. An increasing amount of } \mathrm{CO}_{2} \text { risks will cause more UV } \\
\text { radiation and therefore a larger risk for skin cancer. }(-)\end{array}$ & $20(59)$ & $14(41)$ & 66 & $13(20)$ & $52(80)$ & 35 \\
\hline
\end{tabular}

The teachers had even less knowledge about possible ways to remediate to climate change (Table 5). This situation is reported by most existing research works (Fortner, 2001; Papadimitriou, 2004), even among professional geography teachers (Anyanwu, Le Grange, \& Beets, 2015).

Table 5. Action-related knowledge about climate change. (-) Denotes items with an incorrect statement. Accordingly, responses were reversed to indicate correct and wrong answers. (Tobler et al., 2012). In parentheses, the percentage of subjects for each answer when excluding subjects who declared they do not know

\begin{tabular}{|c|c|c|c|c|c|c|}
\hline \multirow[b]{2}{*}{$\begin{array}{l}\text { For the next few decades, the majority of climate } \\
\text { scientists expect... }\end{array}$} & \multicolumn{3}{|c|}{ Tobler 2012} & \multicolumn{3}{|c|}{ Present sample } \\
\hline & $\%$ right & $\%$ wrong & $\begin{array}{c}\% \text { do } \\
\text { not } \\
\text { know }\end{array}$ & $\%$ right & $\%$ wrong & $\begin{array}{c}\% \text { do } \\
\text { not } \\
\text { know }\end{array}$ \\
\hline $\begin{array}{l}\text { 1. To get in fresh air in winter, it is most climate friendly } \\
\text { to keep a window open for a longer period of time. }(-)\end{array}$ & $93(97)$ & $3(3)$ & 4 & $22(37)$ & $38(63)$ & 40 \\
\hline $\begin{array}{l}\text { 2. A car's average } \mathrm{CO}_{2} \text { emission per person and } \\
\text { kilometer exceeds that of a train many times over. }\end{array}$ & $84(88)$ & $11(12)$ & 5 & $42(79)$ & $11(21)$ & 47 \\
\hline $\begin{array}{l}\text { 3. A large part of the } \mathrm{CO}_{2} \text { emissions in Israel is caused } \\
\text { by the transport sector. }\end{array}$ & $77(90)$ & $8(10)$ & 15 & $65(87)$ & $10(13)$ & 25 \\
\hline $\begin{array}{l}\text { 4. Lettuce from a heated greenhouse causes less } \mathrm{CO}_{2} \\
\text { emissions than field-grown lettuce. (-) }\end{array}$ & $76(80)$ & $18(20)$ & 6 & $23(51)$ & $22(49)$ & 55 \\
\hline $\begin{array}{l}\text { 5. Reducing the temperature of a gas-heated room by } \\
1 \text { degree decreases } \mathrm{CO}_{2} \text { emissions. }\end{array}$ & $70(78)$ & $20(22)$ & 10 & $42(74)$ & $15(26)$ & 43 \\
\hline $\begin{array}{l}\text { 6. The production of } 1 \mathrm{~kg} \text { of beef produces more } \\
\text { greenhouse gases than the production of } 1 \mathrm{~kg} \text { of wheat. }\end{array}$ & $67(71)$ & $27(29)$ & 6 & $35(74)$ & $12(26)$ & 53 \\
\hline $\begin{array}{l}\text { 7. A large part of } \mathrm{CO}_{2} \text { emissions in Israel is produced by } \\
\text { heating. }\end{array}$ & $61(76)$ & $19(24)$ & 20 & $28(51)$ & $27(49)$ & 45 \\
\hline
\end{tabular}




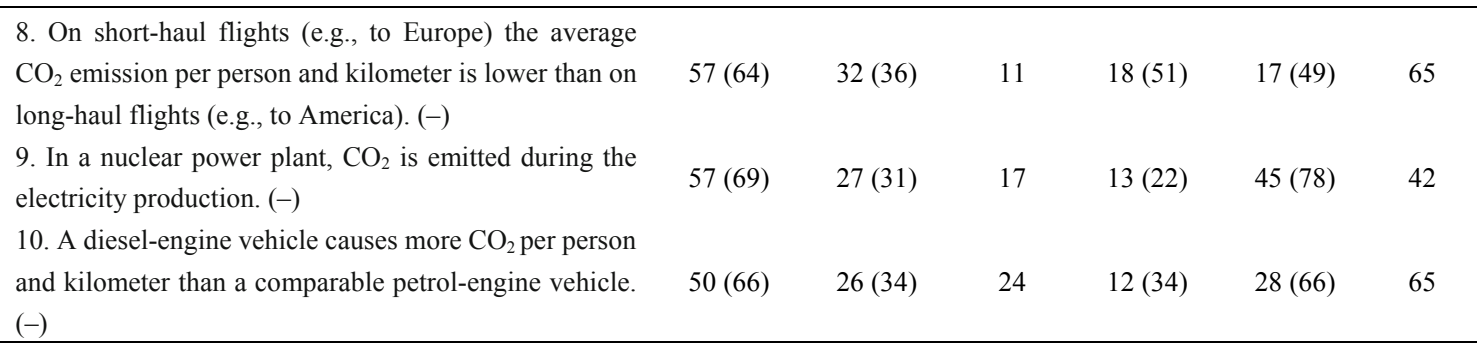

\subsection{Beliefs about Global Warming}

Teachers' answers to questions checking their beliefs about the certainty of climate change, and its anthropogenic origin showed that our sample lay halfway between American and European populations.

In contrast to American studies on preservice teachers (Dawson, 2012), only one single teacher in our sample declared that there was no climate change. To the question "How sure are you that global warming is happening?", $46 \%$ of the teachers answered "extremely sure", $44 \%$ "very sure", $6 \%$ "somewhat sure", and $4 \%$ "not sure". Sixty-two percent (62\%) were convinced that "most scientists think global warming is happening", whereas $20 \%$ thought that "There is a lot of disagreement among scientists about global warming", $6 \%$ thought that "Most scientists think global warming is not happening", and the rest did not know. In American studies (Feldman, Nisbet, Leiserowitz, \& Maibach, 2010; Leiserowitz et al., 2011) the proportion of people thinking that global warming is happening was roughly $60 \%$. It seems that in our sample, the feeling that there is a consensus in the scientific community about the existence of global warming was much stronger than in American studies. Yet the number of teachers thinking that scientists do not agree about the existence of global warming was still no as small as the number of teachers who did not believe that global warming was happening, thus showing that Israeli teachers are aware of the general controversy but mostly take the same side on this issue.

Regarding the anthropogenic origin of climate change (Table 6), the teachers' answers show a lack of consistency which probably stems from the bad understanding of the greenhouse effect observed earlier.

Table 6. Beliefs about the anthropogenic origin of climate change

\begin{tabular}{|c|c|c|c|}
\hline & Agree & $\begin{array}{c}\text { Do not } \\
\text { agree }\end{array}$ & $\begin{array}{c}\text { Do not } \\
\text { know }\end{array}$ \\
\hline The increase of greenhouse gases is mainly caused by human activities. & $70 \%$ & $8 \%$ & $22 \%$ \\
\hline $\begin{array}{l}\text { Global warming is mainly caused by natural variations (such as changes in solar radiation intensity and } \\
\text { volcanic eruptions). }\end{array}$ & $18 \%$ & $57 \%$ & $25 \%$ \\
\hline
\end{tabular}

One could expect that all the teachers accepting that human activities are the main cause of the increase in greenhouse gases would also refute the idea that it is mainly caused by natural variations. Yet the corresponding percentages of teachers were very different (70\% and 57\% respectively) and not inclusive. The belief that global warming is mainly caused by human activities was not so strong in our sample (70\%) as in European studies (82\% in Tobler, 2012) but much higher than in American studies (50\% in Leiserowitz et al., 2012). The percentage of teachers who explicitly attributed global warming to natural causes $(18 \%)$ was similar to the percentage reported among American teachers (Johnson \& Holzer, 2011; Plutzer \& Hannah, 2018; Plutzer, Mccaffrey, Hannah, Rosenau, Berbeco, \& Reid, 2016; Sullivan, Ledley, Lynds, \& Gold, 2014; Wise, 2010).

\subsection{Attitudes about Global Warming}

Concern about climate change (Table 7) was found to be high: $43 \%$ of the teachers expressed that they were very worried and $40 \%$ somewhat worried. In the absence of studies checking this concern among teachers, the comparison of our result to the percentages measured among American university students (Wachholz et al., 2014) (17\% and $48 \%$ respectively) or general population (Feldman et al., 2010; Leiserowitz et al., 2012) shows that the declared level of concern in our sample was much higher. 
Table 7. Concern and readiness to act about global warming

\begin{tabular}{|c|c|c|c|c|c|}
\hline & $\begin{array}{l}\text { Very } \\
\text { much }\end{array}$ & Much & Somewhat & A little & $\begin{array}{c}\text { Not at } \\
\text { all }\end{array}$ \\
\hline Worried & $43 \%$ & $40 \%$ & & $15 \%$ & $2 \%$ \\
\hline $\begin{array}{l}\text { Ready to make specific efforts in the framework of my } \\
\text { regular way of life }\end{array}$ & $28 \%$ & $37 \%$ & $28 \%$ & $5 \%$ & $2 \%$ \\
\hline Ready to change my way of life & $38 \%$ & $40 \%$ & $13 \%$ & $5 \%$ & $4 \%$ \\
\hline $\begin{array}{l}\text { Ready to teach about global warming even if I am not } \\
\text { expected to }\end{array}$ & $35 \%$ & $32 \%$ & $18 \%$ & $8 \%$ & $7 \%$ \\
\hline $\begin{array}{l}\text { Ready to influence my fellow people so that they act in a way } \\
\text { which diminishes global warming }\end{array}$ & $27 \%$ & $38 \%$ & $23 \%$ & $5 \%$ & $7 \%$ \\
\hline
\end{tabular}

The readiness to take steps that help to slow down climate change was also stronger in our sample than in other populations studied (Arslan et al., 2012; Wacholz et al., 2014) but like in all reported results (Ambusaidi et al., 2012; Hermans, 2016), the readiness to act was expressed more weakly than the concern about climate change. And like in other studies (Dawson, 2012), in our sample, not every teacher understanding the issue of climate change was ready to teach about it.

\subsection{Correlations Between Knowledge, Beliefs and Attitudes}

Table 8 reports Pearson correlation coefficients between the different types of knowledge about global warming, belief about the existence of global warming and the two aspects of attitude (concern and readiness to act). The data show on one hand strong correlations between the different types of knowledge about climate change and on the other hand strong correlations between the belief that climate change is happening and the two attitudes.

Table 8. Pearson correlation coefficients between knowledge, beliefs and attitudes about climate change (normalized variables)

\begin{tabular}{llllllll}
\hline & 1 & 2 & 3 & 4 & 5 & 6 & 7 \\
\hline 1. Knowledge about the greenhouse effect & & & & & & & \\
2. Knowledge about causes of climate change & $.692^{* *}$ & & & & & & \\
3. Knowledge about Consequences & $.650^{* *}$ & $.685^{* *}$ & & & & & \\
4. Action-related knowledge & $.613^{* *}$ & $.630^{* *}$ & $.697^{* *}$ & & & & \\
5. Strength of Belief & $.290^{*}$ & $.285^{*}$ & $.400^{* *}$ & $.285^{*}$ & & & \\
6. Concern & .220 & .176 & $.363^{* *}$ & .150 & $.590^{* *}$ & & \\
7. Readiness to act against climate change & .143 & .096 & $.685^{* *}$ & .061 & $.447^{* *}$ & $.655^{* *}$ & \\
mean & 0.467 & 0.470 & 0.492 & 0.300 & 0.842 & 0.812 & 0.772 \\
SD & 0.298 & 0.278 & 0.262 & 0.234 & 0.172 & 0.193 & 0.183 \\
\hline
\end{tabular}

All the kinds of knowledge about climate change were correlated with the belief that it is happening, but the type of knowledge that was the most correlated with belief that climate change is happening and with concern, was the knowledge about the consequences of the process.

The only kind of knowledge that was significantly correlated with the declared readiness to act against climate change was the knowledge about its consequences. Even knowledge about the way to act (action-related knowledge) was not correlated with readiness to act. Other research works found similarly that engagement to reduce climate change was not linked to the level of knowledge about its causes, and they describe very climate-friendly teachers who hold severe misconceptions about climate change (Liu et al., 2015)

We think that considering the knowledge about the consequences of climate change as a mediating factor between instruction received on climate change and readiness to act, can explain the limited impact of academic courses on the engagement of teachers in the fight against climate change. Indeed, academic courses about climate change focus on scientific explanations of the phenomenon rather than on the social and practical aspects of the issue, so that they probably increase teachers' understanding of climate change more than the understanding of the consequences of climate change (Drewes, Henderson, \& Mouza, 2018).

\section{Conclusion}

The results presented in this study show that a majority of teachers in Israel believe that climate change is 
happening and recognize human responsibility for the phenomenon. Yet they still possess many misconceptions and gaps in knowledge about the nature and consequences of climate change, and their readiness to take action is not very high. These results argue for an improvement in teachers' education about climate change stressing the consequences of the phenomenon on every-day life, as well as possible ways of action.

\section{Acknowledgments}

This research was funded by the Shamir Research Institute and Ohalo Academic College.

\section{References}

Ajzen, I (2002). Perceived Behavioral Control, Self-Efficacy, Locus of Control, and the Theory of Planned Behavior. Journal of Applied Social Psychology, 32(4), 665-683. https://doi.org/10.1111/j.1559-1816.2002.tb00236.x

Ambusaidi, A., Boyes, E., Stanisstreet, M., \& Taylor, N. (2012). Omani Students' Views about Global Warming: Beliefs about Actions and Willingness to Act. International Research in Geographical and Environmental Education, 21(1), 21-39. https://doi.org/10.1080/10382046.2012.639154

Anyanwu, R., Le Grange, L., \& Beets, P. (2015). Climate Change Science: The Literacy of Geography Teachers in the Western Cape Province, South Africa. South African Journal of Education, 35(3), Art \#1160. https://doi.org/10.15700/saje.v35n3a1160

Arslan, H. O., Cigdemoglu, C., \& Moseley, C. (2012). A Three-Tier Diagnostic Test to Assess Pre Service Teachers' Misconceptions about Global Warming, Greenhouse Effect, Ozone Layer Depletion, and Acid Rain. International Journal of Science Education, 34(1), 1667-1686. https://doi.org/10.1080/09500693.2012.680618

Avissar, I., Alkaher, I., \& Gan, D. (2018). The role of distributed leadership in mainstreaming environmental sustainability into campus life in an Israeli teaching college: A case study. International Journal of Sustainability in Higher Education, 19(3), 518-546. https://doi.org/10.1108/IJSHE-07-2017-0105

Bell, R. L., Matkins, J. J., \& Gansneder, B. M. (2011). Impacts of Contextual and Explicit Instruction on Preservice Elementary Teachers' Understandings of the Nature of Science. Journal of Research in Science Teaching, 48(4), 414-436. https://doi.org/10.1002/tea.20402

Benjamin, D., Por, H.-H., \& Budescu, D. (2017). Climate Change Versus Global Warming: Who Is Susceptible to the Framing of Climate Change? Environment and Behavior, 49(7), 745-770. https://doi.org/10.1177/0013916516664382

Boon, H. J. (2016). Pre-Service Teachers and Climate Change: A Stalemate? Australian Journal of Teacher Education, 41(4), 39-63. https://doi.org/10.14221/ajte.2016v41n4.3

Boyes, E., \& Chambers, W. (1995). Trainee primary teachers' ideas about the Ozone Layer. Environmental Education Research, 1(2), 133-145. https://doi.org/10.1080/1350462950010201

Capstick, S. B., \& Pigeon, N. F. (2014). What is climate change scepticism? Examination of the concept using a mixed methods study of the UK public. Global Environmental Change, 24, 389-401. https://doi.org/10.1016/j.gloenvcha.2013.08.012

Cimer, S. O., Cimer, A., \& Ursavas, N. (2011). Student Teachers' Conceptions about Global Warming and Changes in Their Conceptions during Pre-Service Education: A Cross Sectional Study. Educational Research and Reviews, 6(8), 592-597.

Dawson, V. (2012). Science Teachers' Perspectives about Climate Change. Teaching Science, 58(3), 8-13.

Dove, J. (1996). Student teachers' understanding of the greenhouse effect, ozone layer depletion, and acid rain. Environmental Education Research, 2, 89-100. https://doi.org/10.1080/1350462960020108

Drewes, A., Henderson, J., \& Mouza, C. (2018). Professional development design considerations in climate change education: teacher enactment and student learning. International Journal of Science Education, 40(1), 67-89. https://doi.org/10.1080/09500693.2017.1397798

Dupigny-Giroux, L.-A. (2010). Exploring the Challenges of Climate Science Literacy: Lessons from Students, Teachers and Lifelong Learners. Geography Compass, 4(9), 1203-1217. https://doi.org/10.1111/j.1749-8198.2010.00368.x

Eagly, A. H., \& Chaiken, S. (1993). The psychology of attitudes. San Diego: Harcourt Brace.

Ekborg, M., \& Areskoug, M. (2006). How student teachers' understanding of the greenhouse effect develops 
during a teacher education programme. NorDiNa, 5, 17-29. https://doi.org/10.5617/nordina.411

Feldman, L., Nisbet, M., Leiserowitz, A., \& Mailbach, E. (2010). The climate generation? Survey analysis of the perceptions and beliefs of young Americans. New Haven CT and Fairfax, VA: Yale University. Yale Project on Climate Change Communication and George Mason University.

Fortner, R. W. (2001). Climate change in school: Where does it fit and how ready are we? Canadian Journal of Environmental Education, 6, 18-31.

Groves F. H., \& Pugh A. F. (1999). Elementary pre-service teachers perceptions of the greenhouse effect. Journal of Science Education and Technology, 8(1), 75-81. https://doi.org/10.1023/A:1009433705790

Hastürk, G., \& Dogan, A. (2016). Effect of Triadic Teaching Approach in Some Environmental Subjects: Prospective Science Teachers Practice. International Journal of Environmental and Science Education, 11(5), 893-905. https://doi.org/10.12973/ijese.2016.323a

Herman, B. C., Feldman, A., \& Vernaza-Hernandez, V. (2017). Florida and Puerto Rico Secondary Science Teachers' Knowledge and Teaching of Climate Change Science. International Journal of Science and Mathematics Education, 15(3), 451-471. https://doi.org/10.1007/s10763-015-9706-6

Hermans, M. (2016). Geography Teachers and Climate Change: Emotions about Consequences, Coping Strategies, and Views on Mitigation. International Journal of Environmental and Science Education, 11(4), 389-408.

Hestness, E., McDonald, R. C., Breslyn, W., McGinnis, J. R., \& Mouza, C. (2014). Science Teacher Professional Development in Climate Change Education Informed by the Next Generation Science Standards. Journal of Geoscience Education, 62(3), 319-329. https://doi.org/10.5408/13-049.1

Hestness, E., McGinnis, J. R., Riedinger, K., \& Marbach-Ad, G. (2011). A study of teacher candidates' experiences investigating global climate change within an elementary science methods course. Journal of Science Teacher Education, 22, 351-369. https://doi.org/10.1007/s10972-011-9234-3

Higde, E., Oztekin, C., \& Sahin, E. (2017). Turkish Pre-Service Science Teachers' Awareness, Beliefs, Values, and Behaviours Pertinent to Climate Change. International Research in Geographical and Environmental Education, 26(3), 253-263. https://doi.org/10.1080/10382046.2017.1330040

Hodson, D. (2013). Don't be nervous, don't be flustered, don't be scared: Be prepared. Canadian Journal of

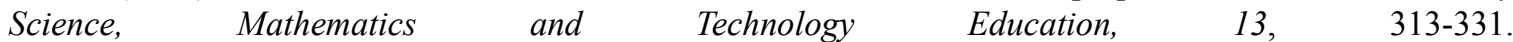
https://doi.org/10.1080/14926156.2013.845327

Ikonomidis, S., Papanastasiou, D., Melas, D., \& Avgoloupis, S. (2012). The Anthropogenic "Greenhouse Effect": Greek Prospective Primary Teachers' Ideas about Causes, Consequences and Cures. Journal of Science Education and Technology, 21(6), 768-779. https://doi.org/10.1007/s10956-012-9365-0

Johnson R. M., \& Holzer, M. (2011). Executive summary: National Earth Science Teachers Association K-12 Climate Change Education Survey. Fort Collins, CO.

Karami, S., Seyed, M. S., Jafari, H., \& Hendi, G. N. (2017). Assessment of knowledge, attitudes, and practices (KAP) towards climate change education (CCE) among lower secondary teachers in Tehran, Iran. International Journal of Climate Change Strategies and Management, 9(3), 402-415. https://doi.org/10.1108/IJCCSM-04-2016-0043

Khalid, T. (2001), "Pre-service teachers' misconceptions regarding three environmental issues". Canadian Journal of Environmental Education, 6, 102-120.

Lambert, J. L., \& Bleicher, R. E. (2013). Climate Change in the Preservice Teacher's Mind. Journal of Science Teacher Education, 24(6), 999-1022. https://doi.org/10.1007/s10972-013-9344-1

Lambert, J. L., \& Bleicher, R. E. (2017). Argumentation as a Strategy for Increasing Preservice Teachers' Understanding of Climate Change, a Key Global Socioscientific Issue. International Journal of Education in Mathematics, Science and Technology, 5(2), 101-112. https://doi.org/10.18404/ijemst.21523

Lambert, J., Lindgren, J., \& Bleicher, R. (2011). Assessing elementary science methods students' understanding about global climate change. International Journal of Science Education, 34(8), 1167-1187. https://doi.org/10.1080/09500693.2011.633938

Leiserowitz, A., Maibach, E., Roser-Renouf, C., \& Smith, N. (2011) Climate change in the American Mind: Americans' global warming beliefs and attitudes in May 2011. Yale University and George Mason 
University. New Haven, CT: Yale Project on Climate Change Communication. Retrieved from http://environment.yale.edu/climate/files/ClimateBeliefsMay2011.pdf

Leiserowitz, A., Smith, N., \& Marlon, J. R. (2012). American Teens' Knowledge of Climate Change. New Haven CT and Fairfax, VA: Yale University. Yale Project on Climate Change Communication and George Mason University.

Lineman, M., Do, Y., Ji-Yoon, K., Gea-Jae, J. (2015). Talking about Climate Change and Global Warming. PLoS One, 10(9), e0138996. https://doi.org/10.1371/journal.pone.0138996

Liu, S., Roehrig, G., Bhattacharya, D., \& Varma, K. (2015). In-Service Teachers' Attitudes, Knowledge and Classroom Teaching of Global Climate Change. Science Educator, 24(1), 12-22.

Lombardi, D., \& Sinatra, G. M. (2012). College students' perceptions about the plausibility of human induced climate change. Research in Science Education, 42, 201-217. https://doi.org/10.1007/s11165-010-9196-z

Lorenzoni, I., \& Pidgeon, N. (2006), Public views on climate change: European and USA perspectives. Climatic Change, 77(1/2), 73-95. https://doi.org/10.1007/s10584-006-9072-z

Matkins, J. J., \& Bell, R. L. (2007). Awakening the Scientist Inside: Global Climate Change and the Nature of Science in an Elementary Science Methods Course. Journal of Science Teacher Education, 18(2), 137-163. https://doi.org/10.1007/s10972-006-9033-4

McCuin, J. L., Hayhoe, K., \& Hayhoe, D. (2014). Comparing the Effects of Traditional vs. Misconceptions-Based Instruction on Student Understanding of the Greenhouse Effect. Journal of Geoscience Education, 62(3), 445-459. https://doi.org/10.5408/13-068.1

McGinnis, J. R., \& Simmons, P. (1999). Teachers' perspectives of teaching science-technology-society in local $\begin{array}{llll}\text { cultures: A sociocultural analysis. Science Education, 83, 179-212. } & \text { A }\end{array}$ https://doi.org/10.1002/(SICI)1098-237X(199903)83:2<179::AID-SCE6>3.0.CO;2-X

McNeal, K. S., Walker, S. L., \& Rutherford, D. (2014). Assessment of 6- to 20-Grade Educators' Climate Knowledge and Perceptions: Results from the Climate Stewardship Survey. Journal of Geoscience Education, 62(4), 645-654. https://doi.org/10.5408/13-098.1

McNeal, P., Petcovic, H., \& Reeves, P. (2017).What is motivating middle-school science teachers to teach climate change? International Journal of Science Education, 39(8), 1069-1080. https://doi.org/10.1080/09500693.2017.1315466

Morgan, J., \& Moran, J. (1996). Understanding the greenhouse effect and the ozone shield: an index of scientific literacy among university students. Bulletin of the American Meteorological Society, 76(7), 1185-1190. https://doi.org/10.1175/1520-0477-76.7.1185

Negev, M., Sagy, G., Garb, Y., Salzberg, A., \& Tal, A. (2008). Evaluating the environmental literacy of Israel elementary and high school students. The Journal of Environmental Education, 39(2), 3-20. https://doi.org/10.3200/JOEE.39.2.3-20

Pajares, F. M. (1992). Teachers' beliefs and educational research: Cleaning up a messy construct. Review of Educational Research, 62, 307-332. https://doi.org/10.3102/00346543062003307

Papadimitriou, V. (2004). Prospective primary teachers' understanding of climate change, greenhouse effect, and ozone layer depletion. Journal of Science Education and Technology, 1(2), 299-307. https://doi.org/10.1023/B:JOST.0000031268.72848.6d

Plutzer, E, Mccaffrey, M., Hannah, A. L., Rosenau, J., Berbeco, M., \& Reid, A. H. (2016). Climate confusion among U.S. teachers. Science, 351(6274), 664-665. https://doi.org/10.1126/science.aab3907

Plutzer, E., \& Hannah, A. L. (2018). Teaching climate change in middle schools and high schools: investigating STEM education's deficit model. Climatic Change, 149(3-4), 305-317. https://doi.org/10.1007/s10584-018-2253-8

Plutzer, E., Hannah, A. L., Rosenau, J., McCaffrey, M. S., Berbeco, M., \& Reid, A. H. (2016). Mixed messages: How climate change is taught in America's public schools. Retrieved from https://ncse.com/libraryresource/mixedmessages-how-climate-change-is-taught-americas-public

Raath, S., \& Hay, A. (2016). Self-efficacy: A South African case study on teachers' commitment to integrate climate change resilience into their teaching practices. Cogent Education, 3(1), Article 1264698. https://doi.org/10.1080/2331186X.2016.1264698 
Risen, J. L., \& Critcher, C. R. (2011). Visceral fit: While in a visceral state, associated states of the world seem more likely. Journal of Personality and Social Psychology, 100(5), 777-793. https://doi.org/10.1037/a0022460

Sadler, T. D., Amirshokoohi, A., Kazempour, M., \& Allspaw, K. M. (2006). Socioscience and ethics in science classrooms: Teacher perspectives and strategies. Journal of Research in Science Teaching, 43, 353-376. https://doi.org/10.1002/tea.20142

Schreiner, C., Henriksen, E. K., Kirkeby H., \& Pål, J. (2005). Climate Education: Empowering Today's Youth to Meet Tomorrow's Challenges. Studies in Science Education, 41(1), 3-49. https://doi.org/10.1080/03057260508560213

Schuldt, J. P., \& Roh, S. (2014). Of Accessibility and Applicability: How Heat-Related Cues Affect Belief in "Global Warming" Versus "Climate Change". Social Cognition, 32(3), 217-238. https://doi.org/10.1521/soco.2014.32.3.217

Seow, T., \& Ho, L.-C. (2016). Singapore Teachers' Beliefs about the Purpose of Climate Change Education and Student Readiness to Handle Controversy. International Research in Geographical and Environmental Education, 25(4), 358-371. https://doi.org/10.1080/10382046.2016.1207993

Shea, N. A., Mouza, C., \& Drewes, A. (2016). Climate Change Professional Development: Design, Implementation, and Initial Outcomes on Teacher Learning, Practice, and Student Beliefs. Journal of Science Teacher Education, 27(3), 235-258. https://doi.org/10.1007/s10972-016-9456-5

Stevenson, K. T., Peterson, M. N., \& Bradshaw, A. (2016). How Climate Change Beliefs among U.S. Teachers Do and Do Not Translate to Students. PLoS One, 11(9), e0161462. https://doi.org/10.1371/journal.pone.0161462

Sullivan, S. M. B., Ledley, T. S., Lynds, S. E., \& Gold, A. U. (2014). Navigating climate science in the classroom: teacher preparation, perceptions and practices. Journal of Geoscience Education, 62(4), 550-559. https://doi.org/10.5408/12-304.1

Tobler, C., Visschers, V., \& Siegrist, M. (2012). Consumers' knowledge about climate change. Climatic Change, 114(2), 189-209. https://doi.org/10.1007/s10584-011-0393-1

United Nations. (2015). Paris Agreement. United Nations.

Valdez, R. X., Peterson, M. N., \& Stevenson, K. T. (2018). How communication with teachers, family and friends contributes to predicting climate change behaviour among adolescents. Environmental Conservation, 45(2), 183-191. https://doi.org/10.1017/S0376892917000443

Wachholz, S., Artz, N., \& Chene, D. (2014). Warming to the idea: university students' knowledge and attitudes about climate change. International Journal of Sustainability in Higher Education, 15(2), 128-141. https://doi.org/10.1108/IJSHE-03-2012-0025

Weintrobe, S. (Ed.) (2013). Engaging with Climate Change. Psychoanalytic and Interdisciplinary Perspectives. London and New York: Routledge. https://doi.org/10.4324/9780203094402

Wise, S. B. (2010). Climate change in the classroom: Patterns, motivations, and barriers to instruction among Colorado science teachers. Journal of Geoscience Education, 58(5), 297-309. https://doi.org/10.5408/1.3559695

\section{Copyrights}

Copyright for this article is retained by the author(s), with first publication rights granted to the journal.

This is an open-access article distributed under the terms and conditions of the Creative Commons Attribution license (http://creativecommons.org/licenses/by/4.0/). 